\title{
Diosmetin induces apoptosis by upregulating p53 via the TGF- $\beta$ signal pathway in HepG2 hepatoma cells
}

\author{
BIN LIU* ${ }^{*}$ YUFENG SHI ${ }^{*}$, WENDING PENG ${ }^{*}$, QINGYU ZHANG, JIE LIU, NIANPING CHEN and RUNZHI ZHU \\ Laboratory of Hepatobiliary Surgery, Guangdong Medical University; Zhanjiang Key Laboratory of Hepatobiliary Diseases, \\ Affiliated Hospital of Guangdong Medical University, Zhanjiang, Guangdong 524001, P.R. China
}

Received June 18, 2015; Accepted April 25, 2016

DOI: $10.3892 / \mathrm{mmr} .2016 .5258$

\begin{abstract}
Diosmetin (Dio) is a major active component of flavonoid compounds. A previous study demonstrated that Dio exhibited anticancer activity and induced apoptosis in HepG2 human hepatoma cells via cytochrome P450, family 1-catalyzed metabolism. The present study observed that cell proliferation of HepG2 cells was inhibited by Dio treatment and tumor protein p53 was significantly increased following Dio treatment. Following addition of recombinant transforming growth factor- $\beta$ (TGF- $\beta$ ) protein to Dio-treated HepG2 cells, cell growth inhibition and cell apoptosis was partially reversed. These findings suggest a novel function for the TGF- $\beta /$ TGF- $\beta$ receptor signaling pathway and that it may be a key target of Dio-induced cell apoptosis in HepG2 cells.
\end{abstract}

\section{Introduction}

Natural products, particularly those that bind to microtubules, are important in the development of anticancer therapeutic agents (1). Diosmetin (Dio) is a flavone compound in various dietary sources, including oregano, citrus fruits, and it may also be extracted from certain medicinal herbs, such as Rosa agrestis Savi (Rosaceae), Chrysanthemum morifolium (Asteraceae) and Dianthus versicolor Fisch (Caryophyllaceae) (2,3). Flavonoids are considered be associated with a variety of beneficial effects, including antioxidant activity (4), which protect tissues against oxidative stress and associated pathologies, such as inflammation (5).

Correspondence to: Professor Nianping Chen or Dr Runzhi Zhu, Laboratory of Hepatobiliary Surgery, Guangdong Medical University; Zhanjiang Key Laboratory of Hepatobiliary Diseases, Affiliated Hospital of Guangdong Medical University, 57 Renmin Road, Zhanjiang, Guangdong 524001, P.R. China

E-mail: hepatolab@163.com

E-mail: runzhizhu1978@163.com

*Contributed equally

Key words: diosmetin, TGF- $\beta$, HepG2, apoptosis
Dio is used in traditional Mongolian medicine to treat liver diseases (6). Hepatocellular carcinoma (HCC) is a global health problem (7) and therapeutic strategies for HCC are predominantly focused on chemotherapy, for example, the alkylating agent cisplatin or the topoisomerase inhibitor doxorubicin (8).

Dio exerts synergistic cytostatic effects in HepG2 cells via cytochrome P450, family 1 (CYP1)-catalyzed metabolism, activation of c-Jun $\mathrm{N}$-terminal kinase (JNK)/extracellular signal-regulated kinase (ERK) and tumor protein p53 (p53)/cyclin-dependent kinase inhibitor 1A upregulation (3). The differential expression of CYP1 enzymes in cancer cells has been proposed to be a potential therapeutic target and the CYP1 family has been implicated in carcinogenesis (9). It was reported that Dio was metabolized to luteolin via an aromatic demethylation reaction on the B-ring by CYP1 member A1 (CYP1A1), CYP1 member B1 (CYP1B1) and the hepatic isozyme CYP1 member A2 (CYP1A2). CYP1A1 and CYP1A2 also produce additional unidentified metabolites in breast adenocarcinoma cells (10). A previous study has investigated the metabolism of the flavonoids using recombinant CYP1A1, CYP1B1 and CYP1A2 enzymes, an investigated their anti-proliferative activity in the MDA-MB-468 and MCF-7 human breast adenocarcinoma cell lines and the MCF-10A normal breast cell line (11).

Transforming growth factor- $\beta$ (TGF- $\beta$ ) is, like activins, inhibins and bone morphogenetic proteins, an important polypeptide growth factors (12). The majority of human tumors, including melanoma, secrete large quantities of TGF- $\beta$, which directly influences the microenvironment and promote tumor growth, peritumoral angiogenesis and dissemination (13). Furthermore, TGF- $\beta$ may increase the motility and invasion of certain cancer cells (14). TGF- $\beta$ exerts its effects via TGF- $\beta$ receptor type I (T $\beta \mathrm{RI})$ and type II (T $\beta \mathrm{RII})$ receptors. The activated T $\beta$ RI initiates an intracellular signaling pathway by phosphorylating the receptor-regulated Smads (R-Smads), which include Smad2 and Smad3. Activated R-Smads form heteromeric complexes with Smad4, which build up in the nucleus and regulate the transcription of target genes (15). p53 is a tumor suppressor that affects genomic stability and triggers apoptosis following cellular exposure to a variety of stressors (16). p53 also promotes transcription and may regulate the transcription and expression of a range of target genes, which leads to cell cycle arrest and apoptosis. These target genes include B-cell lymphoma 2 (Bcl-2) and BCL2-associated 
X protein (Bax) expression (17). Thus, the aim of the present study was to investigate the association between TGF- $\beta$ and Dio-induced cell apoptosis in HepG2 cells.

\section{Materials and methods}

Compounds and reagents. Diosmetin $\left(\mathrm{C}_{16} \mathrm{H}_{12} \mathrm{O}_{6}\right.$; Fig. $\left.1 \mathrm{~A}\right)$ was purchased from Sigma-Aldrich (St. Louis, MO, USA). The original concentration of Dio stored at $-20^{\circ} \mathrm{C}$ was $10 \mathrm{mg} / \mathrm{ml}$. TGF- $\beta$ human recombinant was purchased from Prospec-Tany TechnoGene, Ltd. (East Brunswick, NJ, USA) and anti-human antibodies against p53, Bcl-2, Bax, TGF- $\beta$, TRRII, Smad3, phosphorylated (p)-Smad2/3 and GADPH were all purchased from Cell Signaling Technology, Inc. (Danvers, MA, USA). Horseradish peroxidase (HRP)-conjugated goat anti-rabbit immunoglobulin $\mathrm{G}$ ( $\mathrm{IgG}$ ) secondary antibody was obtained from EarthOx Life Sciences, LLC (Millbrae, CA, USA). Cell Counting Kit-8 (CCK8) and 3-(4,5-dimethyl-2-thiazolyl)-2,5-diphenyl-2-H-tetrazolium bromide (MTT) were purchased from Beyotime Institute of Biotechnology (Haimen, China).

Cell culture and Dio treatment. HepG-2 cells were provided by the Affiliated Hospital of Guangdong Medical College (Zhanjiang, China). The cells were maintained in a humidified atmosphere of $5 \% \mathrm{CO}_{2}$ at $37^{\circ} \mathrm{C}$, and cultured in RPMI-1640 medium (Gibco; Thermo Fisher Scientific, Inc., USA) supplemented with $10 \%(\mathrm{v} / \mathrm{v})$ fetal bovine serum (Gibco; Thermo Fisher Scientific, Inc.), $100 \mathrm{U} / \mathrm{ml}$ penicillin and $100 \mathrm{U} / \mathrm{ml}$ streptomycin. HepG2 cells were grown in standard media, and when $60-70 \%$ confluent, the cells were treated with different concentrations of Dio (5, 10 and $15 \mu \mathrm{g} / \mathrm{ml})$ or TGF- $\beta$ protein/Dio $(10 \mu \mathrm{g} / \mathrm{ml})$ for $24 \mathrm{~h}$. Images were captured by microscopy (magnification, $\mathrm{x} 100$ ).

Annexin V/propidium iodide (PI) double staining. Apoptotic cells $\left(2 \times 10^{4}\right.$ cells $)$ were quantified with an Annexin V-fluorescein isothiocyanate (FITC)/PI kit (BD Biosciences, Franklin Gardens, NJ, USA) and detected with the FACSCalibur ${ }^{\mathrm{TM}}$ flow cytometer (BD Biosciences). Data were analyzed with Modfit 3.2 and BD FACSDiva 6.1.3 software (BD Biosciences). Briefly, cells were pretreated with $5,10,15$ and $20 \mu \mathrm{g} / \mathrm{ml}$ Dio for $24 \mathrm{~h}$ and washed with phosphate-buffered saline (PBS), and then cells were collected and resuspended in binding buffer $[10 \mathrm{mM}$ 4-(2-hydroxyethyl)-1-piperazineethanesulfonic acid ( $\mathrm{pH} 7.5$ ), $2.5 \mathrm{mM} \mathrm{CaCI}_{2}$ and $\left.140 \mathrm{mM} \mathrm{NaCI}\right]$. Cells were incubated with Annexin V-FITC and PI for $15 \mathrm{~min}$ in the dark, prior to flow cytometric analysis. Annexin V-positive cells indicated early stage apoptosis, whereas Annexin V and PI-positive cells indicated late stage apoptosis.

MTT and CCK8 analysis. HepG2 cell density was adjusted to $2 \times 10^{4}$ cells $/ 100 \mu 1$, and the cells were seeded into 96 -well plates and placed in an incubator overnight $\left(37^{\circ} \mathrm{C}\right.$ in $\left.5 \% \mathrm{CO}_{2}\right)$ to allow for attachment and recovery. MTT and CCK8 analyses were performed separately. Briefly, cells were pretreated with 5, 10,15 and $20 \mu \mathrm{g} / \mathrm{ml}$ Dio for $24 \mathrm{~h}$. A total of $20 \mu \mathrm{l}$ MTT solution $(5 \mathrm{mg} / \mathrm{ml}$ in PBS) solution was transferred to each well to yield a final $120 \mu \mathrm{l} /$ well and to separate wells a total of $10 \mu 1$ CCK $8(5 \mathrm{mg} / \mathrm{ml}$ in PBS) was transferred. The plates were incubated for $4 \mathrm{~h}$ at $37^{\circ} \mathrm{C}$ in $5 \% \mathrm{CO}_{2}$ and the absorbance was recorded using the EnSpire ${ }^{\mathrm{TM}} 2300$ Multilabel Plate Reader (PerkinElmer, Inc., Waltham, MA, USA) at wavelengths of $595 \mathrm{~nm}$ and $450 \mathrm{~nm}$, respectively. The half maximal inhibitory concentration $\left(\mathrm{IC}_{50}\right)$ of Dio was calculated using software (Shmm, 1.0.0.0).

Western blotting. Cells were collected and lysed in lysis buffer [100 mM Tris-HCI (pH 6.8), 4\% (m/v) sodium dodecylsulfonate (SDS), $20 \%$ (v/v) glycerol, $200 \mathrm{mM}$ 2-mercaptoethanol, $1 \mathrm{mM}$ phenylmethyl sulfonylfluoride and $1 \mathrm{~g} / \mathrm{ml}$ aprotinin] for $30 \mathrm{~min}$ on ice. The lysates were separated using centrifugation at $4^{\circ} \mathrm{C}$ for $15 \mathrm{~min}$ at $3,913 \mathrm{xg}$. The total protein concentration in the supernatants was detected using the BCA Protein assay kit (Beyotime Institute of Biotechnology). Proteins $(20 \mu \mathrm{g})$ were separated using 8-15\% SDS-PAGE and subsequently transferred to nitrocellulose membranes. These were saturated with 5\% milk in Tris-buffered saline and 1\% Tween-20 (TBST) and incubated with the following primary antibodies in a diluent overnight at $4^{\circ} \mathrm{C}$ : p53 (9282), Bcl-2 (2876), Bax (2772), TGF- $\beta$ (3711), TGF- $\beta$ RII (11888), Smad3 (9513), p-Smad2/3 (8828) and GAPDH (2118) (all 1:1,000; Cell Signaling Technology). Membranes were washed three times with TBST and incubated with HRP-conjugated goat anti-rabbit IgG (E030120-01; EarthOx Life Sciences) for $1 \mathrm{~h}$ at room temperature, followed by washing four times with TBST. An enhanced chemiluminescence kit (GE Healthcare Life Sciences, Chalfont, UK) was added to the membrane and detection was performed using an Odyssey ${ }^{\circledast} \mathrm{CLx}$ Infrared Imaging system (LI-COR Biosciences, Lincoln, NE, USA).

Immunofluorescence (IF). Cells were seeded into 6-well plates were pretreated with $10 \mu \mathrm{g} / \mathrm{ml}$ Dio for $24 \mathrm{~h}$. All floating and attached cells were harvested and fixed with ice-cold $4 \%$ formaldehyde for $10 \mathrm{~min}$ and then washed with ice-cold PBS. Cells were permeabilized with $0.3 \%$ Triton X-100, washed with ice-cold PBS and stained with the following primary antibodies against: p53 (9282), p-p53(Ser15) (9284), p-p53(Ser46) (2521), p-p53(Ser20) (9287), p-p53(Thr81) (2676), p-p53(Ser37) (9289), p-p53(Thr18) (2529) and p-p53(Ser33) (2526) (all 1:500; Cell Signaling Technology, Inc.). Cells were subsequently incubated with Alexa Fluor ${ }^{\circledR}$ secondary antibodies (Invitrogen; Thermo Fisher Scientific, Inc.). Following staining with 4',6-diamidino-2-phenylindole (DAPI), cells and nuclei were observed with a fluorescence microscope (Leica TCS SP5II, Leica Microsystems GmbH, Germany) at wavelengths of $520 \pm 20 \mathrm{~nm}$ and blue fluorescence at $460 \mathrm{~nm}$.

Statistical analysis. Data from the present study were analyzed using GraphPad Prism 5 (GraphPad Software, Inc. La Jolla, CA, USA). Data are presented as the mean \pm standard deviation from triplicate experiments unless otherwise stated. Statistical differences were assessed using the Student's t-test and ${ }^{~} \mathrm{P}<0.05$ was considered to indicate a statistically significant difference.

\section{Results}

Dio inhibits cell proliferation and promotes cell apoptosis. It was demonstrated that untreated HepG2 cells grew well and 
A<smiles>COc1ccc(-c2cc(=O)c3c(O)cc(O)cc3o2)cc1O</smiles>

B

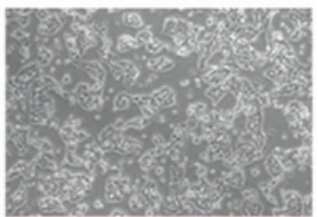

Control

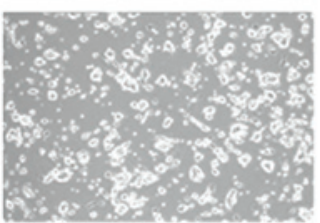

$10 \mu \mathrm{g} / \mathrm{ml}$

D

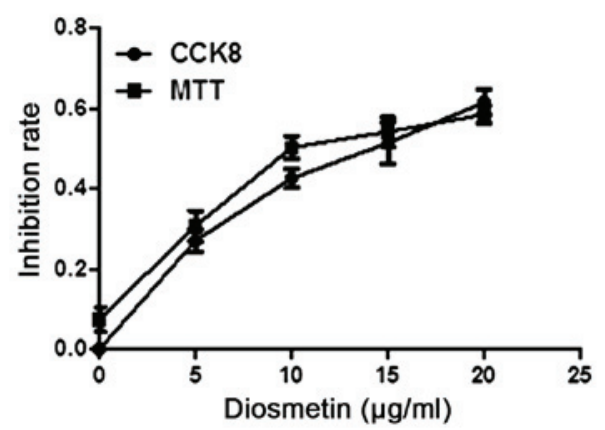

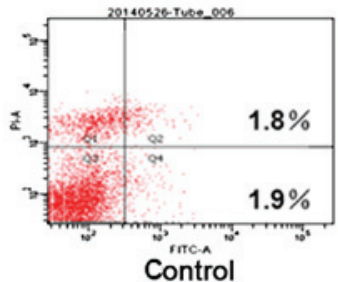

Control

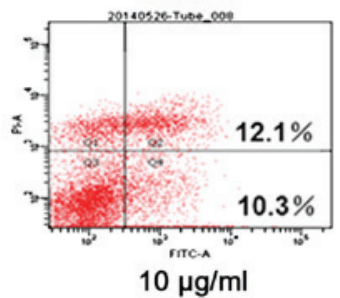

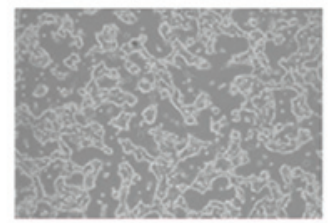

$5 \mu \mathrm{g} / \mathrm{ml}$

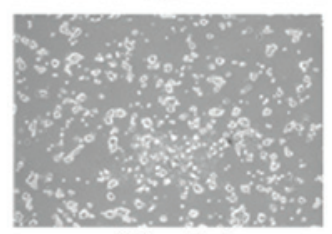

$15 \mu \mathrm{g} / \mathrm{ml}$

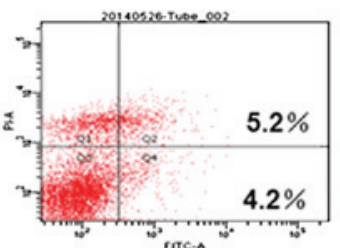

$5 \mu \mathrm{g} / \mathrm{ml}$

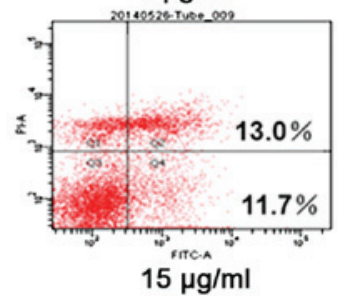

Figure 1. Dio specifically induces apoptosis in HepG2 cells. (A) Chemical structure of Dio. (B) Cell proliferation in HepG2 cells treated with different concentrations $(5,10$, and $15 \mathrm{ug} / \mathrm{ml})$ of Dio for $24 \mathrm{~h}$ were visualized by microscopy (magnification, x100). (C) Cell growth inhibition rates with different concentrations $(5,10,15$ and $20 \mathrm{ug} / \mathrm{ml})$ of Dio for $24 \mathrm{~h}$ were analyzed by MTT and CCK8 methods. (D) Cell apoptosis treated with different concentrations (5, 10 and $15 \mathrm{ug} / \mathrm{ml}$ ) of Dio for $6 \mathrm{~h}$ were visualized by flow cytometry. Dio, diosmetin; CCK8, Cell Counting Kit-8.

A

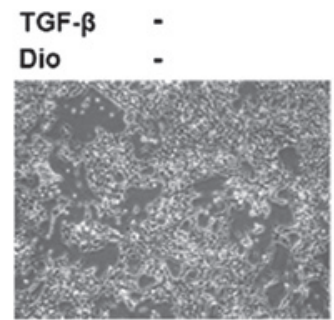

B

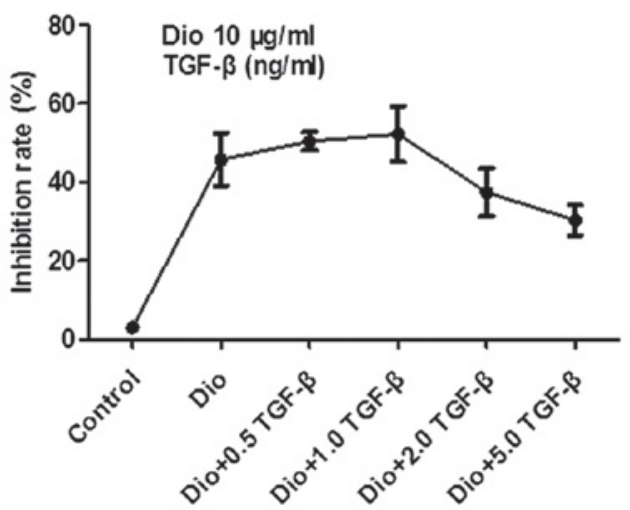

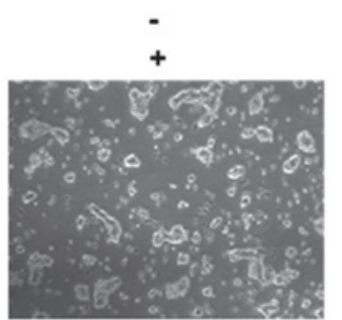

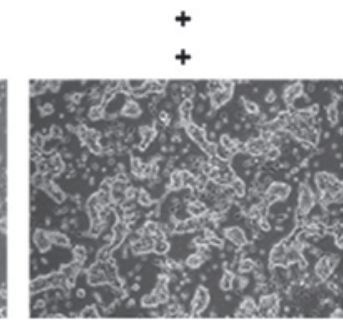

C

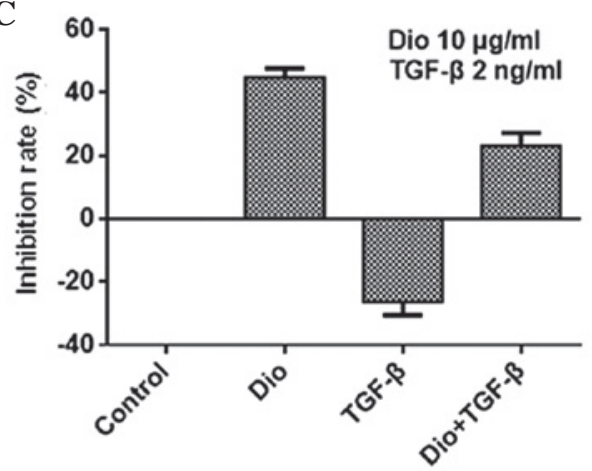

Figure 2. TGF- $\beta$ partly ameliorated Dio-mediated cell apoptosis. (A) TGF- $\beta$ ( $2 \mathrm{ng} / \mathrm{ml})$ reversed Dio (10 $\mu \mathrm{g} / \mathrm{ml})$-induced cell apoptosis (magnification, $\mathrm{x} 100)$; (B) Cell were treated with $10 \mu \mathrm{g} / \mathrm{ml}$ Dio and different TGF- $\beta$ protein concentrations for $24 \mathrm{~h}$, and cell growth inhibition rates were analyzed by MTT assay. (C) Cells were treated with $10 \mu \mathrm{g} / \mathrm{ml}$ Dio and $2 \mathrm{ng} / \mathrm{ml}$ TGF- $\beta$ protein for $24 \mathrm{~h}$, and cell growth inhibition rates were analyzed by MTT assay. Dio, diosmetin; TGF- $\beta$, transforming growth factor- $\beta$. 
A
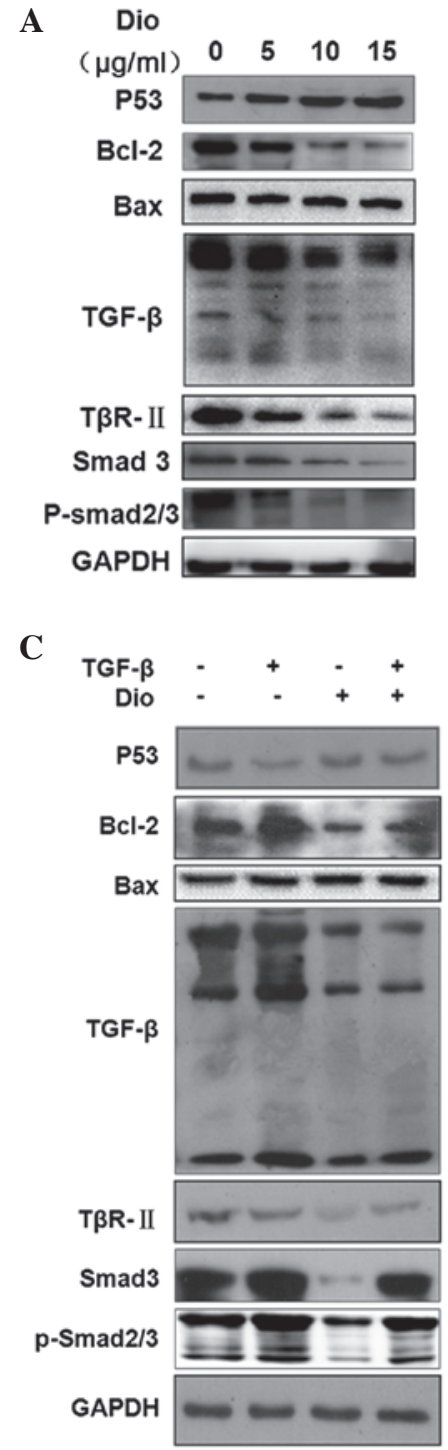

B

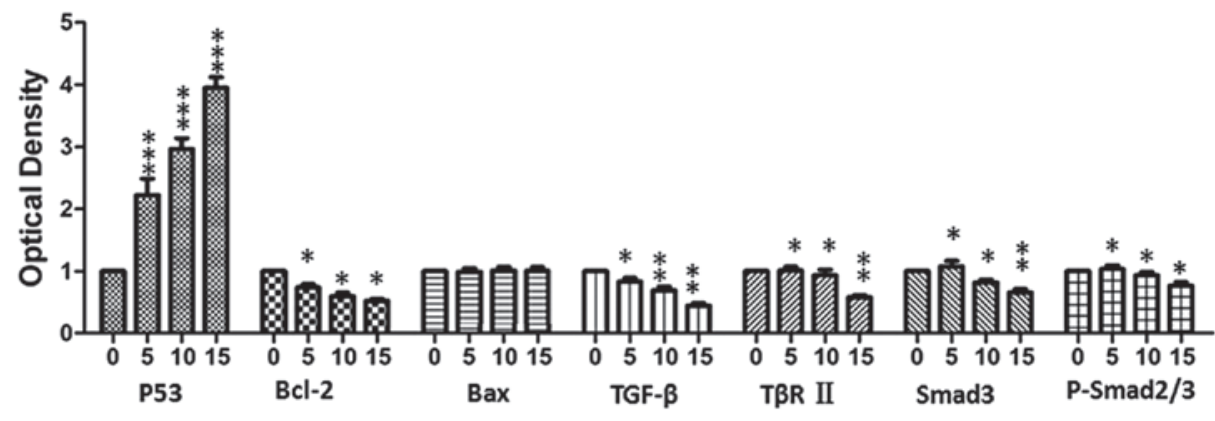

D

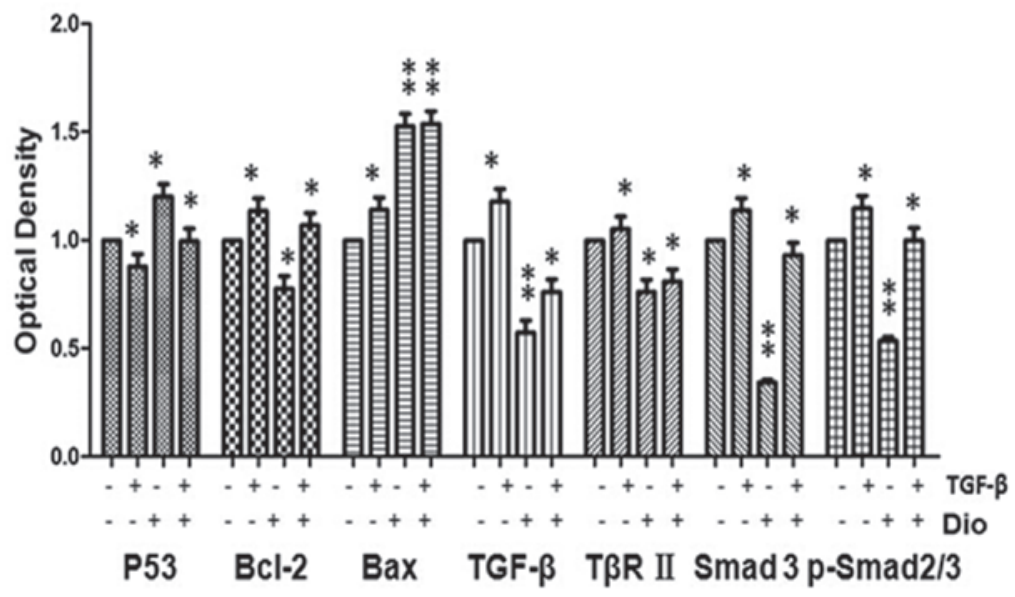

Figure 3. Western blotting analysis was conducted to detect the effects of Dio on the TGF- $\beta$ signaling pathway and apoptosis-associated proteins in HepG2 cells. (A and B) Cells were treated with different concentration $(5,10$ and $15 \mu \mathrm{g} / \mathrm{ml})$ of Dio for $24 \mathrm{~h}$ and proteins were detected. (C and D) Cells were treated with TGF- $\beta(2 \mathrm{ng} / \mathrm{ml})$ and Dio $(15 \mu \mathrm{g} / \mathrm{ml})$ for $24 \mathrm{~h}$ and proteins were detected. All western blots were representatives of three independent experiments. "P<0.05, ${ }^{* *} \mathrm{P}<0.01$ or ${ }^{* * * *} \mathrm{P}<0.001$ vs. the untreated group. Dio, diosmetin; TGF- $\beta$, transforming growth factor- $\beta$; p53, tumor protein p53; Bcl-2, B-cell lymphoma 2 ; Bax, BCL2-associated X protein; T $\beta$ R II, TGF- $\beta$ receptor II.

were observed to have with normal skeletons, whereas cells treated with Dio were distorted and a number of them became round and floating. The number of normal cells was reduced, and sloughed cells were increased in a concentration-dependent manner (Fig. 1B). MTT and CCK8 analysis was used to evaluate the inhibitory effects of Dio in HepG2 cells. Results from the present study demonstrate that Dio inhibits cell proliferation in HepG2 cells in a concentration-dependent manner (Fig. 1C). Cell apoptosis was detected by flow cytometry with the results indicating that Dio may induce cell apoptosis in a concentration-dependent manner (Fig. 1D). In the early stages of apoptosis, cells were Annexin V-positive (Q4), whereas Annexin V and PI-positive cells were considered to be in the late stage of apoptosis $(\mathrm{Q} 2)$. The $\mathrm{IC}_{50}$ of Dio was determined to be $12.0 \mu \mathrm{g} / \mathrm{ml}$.

TGF- $\beta$ is important in Dio-triggered apoptosis. To investigate whether cell growth reversed following recombinant TGF- $\beta$ administration, HepG 2 cells were treated with $10 \mu \mathrm{g} / \mathrm{ml}$ Dio and different concentrations of TGF- $\beta$ and images were captured using microscopy (magnification, x100; Fig. 2A and B). Cells were treated with or without Dio $(10 \mu \mathrm{g} / \mathrm{ml})$ and with or without TGF- $\beta$ ( $2 \mathrm{ng} / \mathrm{ml})$ for $24 \mathrm{~h}$. The MTT assay was performed to detect the proliferation inhibition rate of the cells (Fig. 2C), and the inhibition rate of cells treated with Dio $(10 \mu \mathrm{g} / \mathrm{ml})$ and TGF- $\beta(2 \mathrm{ng} / \mathrm{ml})$ was comapred with Dio treatment, however, higher than that of TGF- $\beta$ treatment.

Dio regulates expression levels of apoptosis-associated proteins and TGF- $\beta$ signaling pathway protein. As cell apoptosis is associated with the Bcl-2-associated mitochondria-dependent apoptosis signaling pathway (18), the present study further investigated the link between 553 and Bcl-2 in HepG-2 cells treated with Dio (Fig. 3). Cells were exposed to $0,5,10$ or $15 \mu \mathrm{g} / \mathrm{ml}$ Dio for $24 \mathrm{~h}$ and the expression levels of p53 were demonstrated to be upregulated in a dose-dependent 


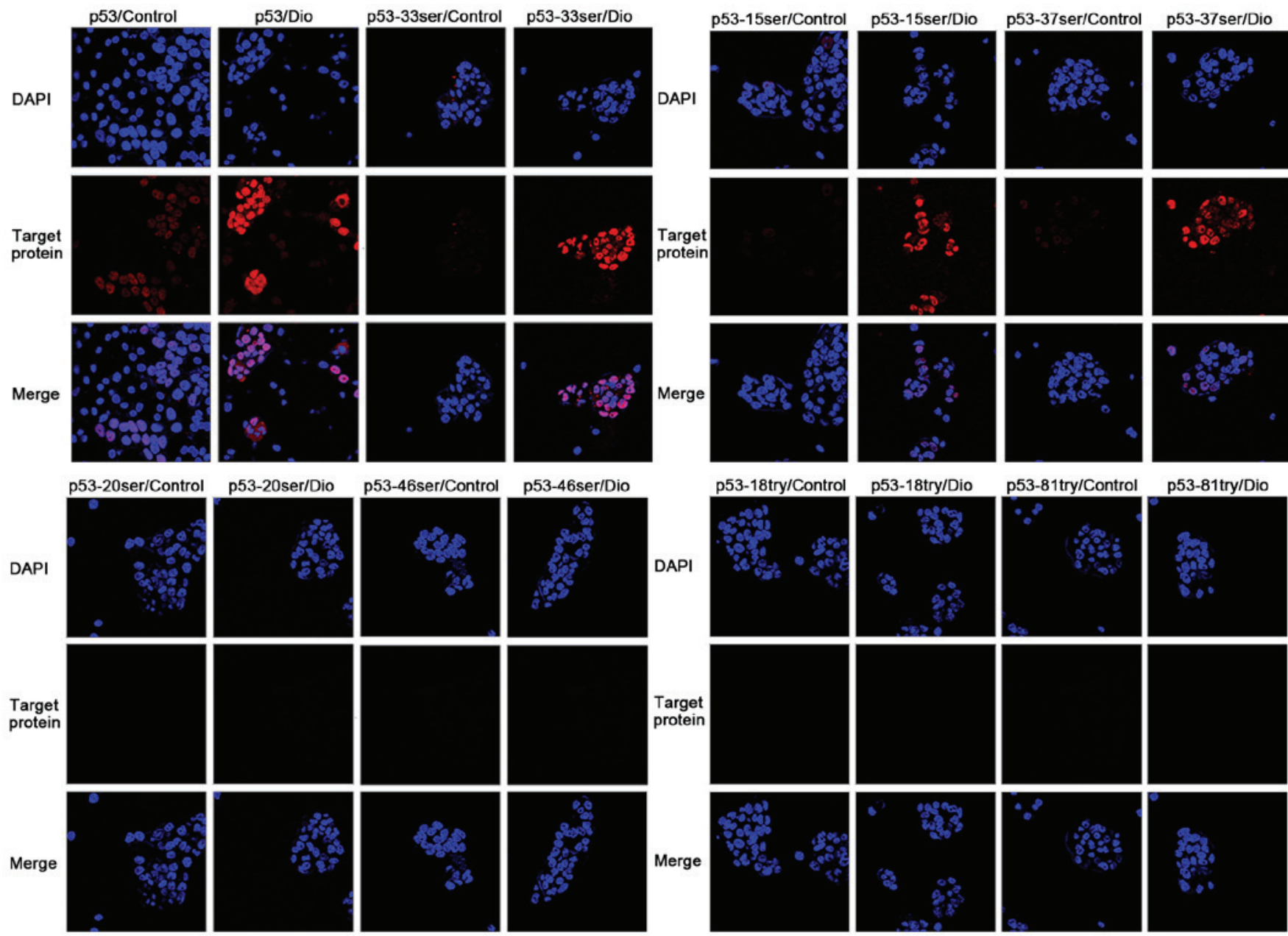

Figure 4. Dio induces HepG2 cells apoptosis by enhancing p53 expression and phosphorylation. $10 \mu \mathrm{g} / \mathrm{ml}$ Dio treated cells for $24 \mathrm{~h}$, and then p53 and phosphorylated-p53 protein expression levels were determined by immunofluorescence (magnification, x200). p53, tumor protein p53; Dio, diosmetin; DAPI, 4',6-diamidino-2-phenylindole.

manner $(\mathrm{P}<0.001)$, while $\mathrm{Bcl}-2$ was downregulated in a dose-dependent manner $(\mathrm{P}<0.01)$. Protein expression levels of TGF- $\beta$, T $\beta$ RII, Smad 3 and $\mathrm{p}-\mathrm{Smad} 2 / 3$ were reduced, also in a dose-dependent manner $(\mathrm{P}<0.05$; Fig. 3A). Bax protein expression levels show no change compared with the control. The results demonstrated that cell growth was partially reversed following treatment with recombinant TGF- $\beta$. Correspondingly, Bcl-2, TGF- $\beta$, T $\beta$ RII, Smad 3 and P-Smad $2 / 3$ increased when stimulated by TGF- $\beta$ compared with the control. Furthermore, p53 protein expression levels decreased when stimulated by TGF- $\beta$ compared with the control and Bax protein expression levels showed no change when compared with the control. p53 protein expression levels decreased when with TGF- $\beta$ protein and Dio, compared with Dio treatment alone, while protein expression levels of $\mathrm{Bcl}-2$, TGF- $\beta$, T $\beta$ RII, Smad3 and p-Smad2/3 (Fig. 3C).

Dio induces apoptosis by enhancing p53 expression and phosphorylation at Ser15, 33 and 37. p53 is important in the cellular response to DNA damage and other genomic aberrations. Activation of p53 may lead to cell cycle arrest and DNA repair, or apoptosis (19). Bcl-2 protein expression levels were reduced and total p53 expression was increased in HepG2 cells treated with Dio for $24 \mathrm{~h}$. Using IF microscopy, nuclear accumulation of p-p53 (at Ser15, 33 and 37) was observed (Fig. 4). It was observed that following Dio treatment for $24 \mathrm{~h}$, p53 phosphorylation increased at Ser15, 33 and 37, however, no marked increase was detected at Ser20,46, Try18 or 81.

\section{Discussion}

Natural products have been widely used in the development of anticancer therapeutic agents, although the underlying mechanisms of cancer cell suppression remain to be elucidated (20). Previous studies into Dio-induced cell apoptosis predominantly focused on cytochrome P450 $(11,21)$. Dio exerts cytostatic effects in MDA-MB 468 cells, due to CYP1A1 and CYP1B1-catalyzed conversion to the flavone luteolin and CYP1 enzymes increase the antiproliferative activity of dietary flavonoids in breast cancer cells $(9,11)$. Cyp26 b1 regulates retinoic acid-dependent signals in $\mathrm{T}$ cells and its expression is inhibited by transforming growth factor- $\beta$ (22). To increase understanding of TGF- $\beta$ signal participation, HepG2 cells were treated with different concentrations of Dio and cell growth was observed. Cell growth was inhibited and the expression levels of apoptosis-associated and TGF- $\beta$ signaling pathway-associated proteins was altered. However, following TGF- $\beta$ administration, cell apoptosis was partly reversed. 
TGF- $\beta$ signaling pathway-associated proteins were also regulated. Notably, Dio reduced T $\beta$ RII expression levels, however, addition of exogenous TGF- $\beta$ protein regulated Dio-induced inhibition of cell proliferation and apoptosis, which indicates that TGF- $\beta$ signaling pathway is key in Dio-induced cancer cell apoptosis. The present study hypothesized that exogenous TGF- $\beta$ protein compensates for decrease in receptor expression levels. TGF- $\beta$ and TGF- $\beta$ receptor binding initiates a range of cellular responses via binding to and activation of specific cell surface receptors with intrinsic serine/threonine kinase activity. These activated TGF- $\beta$ receptors stimulate the phosphorylation of R-Smad proteins, which have been identified as important in regulating the expression levels of extracellular matrix proteins via the TGF- $\beta$ signaling pathway $(23,24)$.

p53 uses various cellular inputs to regulate apoptosis, proliferation and differentiation $(25,26)$. p53 has also been associated with cancer cell metastasis, metabolism and small $\mathrm{G}$ protein signal transduction. p53 can induce apoptosis in response to multiple stimuli via cell growth arrest, apoptosis and senescence $(16,27)$. As a transcriptional factor, p53 regulates transcription and expression of a variety of target genes, such as Bcl-2 and Bax, ultimately leading to cell cycle arrest and apoptosis $(19,28)$. The present study demonstrated that Dio significantly upregulates p53 expression and increases the ratio of Bax/Bcl-2 proteins in cells treated with Dio, which suggests p53 and Bax/Bcl-2 proteins are key in Dio-induced cell apoptosis. Furthermore, Dio increases intracellular p53 protein expression level, particularly the p-p53 at Ser15, 33 and 37. p53 may be phosphorylated by ataxia telangiectasia mutated, ataxia telangiectasia and $\operatorname{Rad} 3$ related, and DNA-depended protein kinase. Phosphorylation impairs the ability of MDM2 proto-oncogene to bind p53, promoting accumulation and activation of p53 in response to DNA damage. Exogenous TGF- $\beta$ partly reverses Dio-induced cell apoptosis in HepG2 cells, which demonstrates that TGF- $\beta / T \beta R$ II signaling pathway may be an important target for therapeutic agents based on Dio-induced cell apoptosis in HepG2 cells.

\section{Acknowledgements}

The present study was supported in part by grants from the Zhanjiang 2013 Annual Financial Capital Competitive Project Science and Technology Project, Zhanjiang Key Laboratory of Hepatobiliary Diseases (grant no. 2013A402-4), Zhanjiang 2014 Annual Financial Capital Competitive Project Science and Technology Project (grant no. 2014A01029), the Start Project of Doctor Scientific Research Funds, Affiliated Hospital of Guangdong Medical College (grant no. B2012039).

\section{References}

1. Yue QX, Liu X and Guo DA: Microtubule-binding natural products for cancer therapy. Planta Med 76: 1037-1043, 2010.

2. Bitis L, Kultur S, Melikoglu G, Ozsoy N and Can A: Flavonoids and antioxidant activity of Rosa agrestis leaves. Nat Prod Res 24: 580-589, 2010

3. Androutsopoulos VP and Spandidos DA: The flavonoids diosmetin and luteolin exert synergistic cytostatic effects in human hepatoma HepG2 cells via CYP1A-catalyzed metabolism, activation of JNK and ERK and P53/P21 up-regulation. J Nutr Biochem 24: 496-504, 2013.
4. Rice-Evans CA, Miller NJ and Paganga G: Structure-antioxidant activity relationships of flavonoids and phenolic acids. Free Radic Biol Med 20: 933-956, 1996.

5. Quintieri L, Bortolozzo S, Stragliotto S, Moro S, Pavanetto M, Nassi A, Palatini P and Floreani M: Flavonoids diosmetin and hesperetin are potent inhibitors of cytochrome P450 2C9-mediated drug metabolism in vitro. Drug Metab Pharmacokinet 25: 466-476, 2010.

6. Obmann A, Werner I, Presser A, Zehl M, Swoboda Z Purevsuren S, Narantuya S, Kletter C and Glasl S: Flavonoid $\mathrm{C}$-and O-glycosides from the Mongolian medicinal plant Dianthus versicolor Fisch. Carbohydr Res 346: 1868-1875, 2011.

7. Yang JD and Roberts LR: Hepatocellular carcinoma: A global view. Nat Rev Gastroenterol Hepatol 7: 448-458, 2010.

8. Poon RT and Borys N: Lyso-thermosensitive liposomal doxorubicin: An adjuvant to increase the cure rate of radiofrequency ablation in liver cancer. Future Oncol 7: 937-945, 2011.

9. Androutsopoulos VP, Mahale S, Arroo RR and Potter G: Anticancer effects of the flavonoid diosmetin on cell cycle progression and proliferation of MDA-MB 468 breast cancer cells due to CYP1 activation. Oncol Rep 21: 1525-1528, 2009.

10. Androutsopoulos V, Wilsher N, Arroo RR and Potter GA: Bioactivation of the phytoestrogen diosmetin by CYP1 cytochromes P450. Cancer Lett 274: 54-60, 2009.

11. Androutsopoulos VP, Ruparelia K, Arroo RR, Tsatsakis AM and Spandidos DA: CYP1-mediated antiproliferative activity of dietary flavonoids in MDA-MB-468 breast cancer cells. Toxicology 264: 162-170, 2009.

12. Drabsch Y and ten Dijke P: TGF- $\beta$ signaling in breast cancer cell invasion and bone metastasis. J Mammary Gland Biol Neoplasia 16: 97-108, 2011.

13. Busse A and Keilholz U: Role of TGF- $\beta$ in melanoma. Curr Pharm Biotechnol 12: 2165-2175, 2011.

14. HeldinCH,LandströmMandMoustakas A:Mechanism ofTGF-beta signaling to growth arrest, apoptosis, and epithelial-mesenchymal transition. Curr Opin Cell Biol 21: 166-176, 2009.

15. Meulmeester E and ten Dijke P: The dynamic roles of TGF- $\beta$ in cancer. J Pathol 223: 205-218, 2011.

16. Zhang Q, Liu J, Liu B, Xia J, Chen N, Chen X, Cao Y, Zhang C, Lu C, Li M and Zhu R: Dihydromyricetin promotes hepatocellular carcinoma regression via a p53 activation-dependent mechanism. Sci Rep 4: 4628, 2014.

17. Wu S, Liu B, Zhang Q, Liu J, Zhou W, Wang C, Li M, Bao S and Zhu R: Dihydromyricetin reduced Bcl-2 expression via p53 in human hepatoma HepG2 cells. PloS One 8: e76886, 2013.

18. Youle RJ and Strasser A: The BCL-2 protein family: Opposing activities that mediate cell death. Nat Rev Mol Cell Biol 9: 47-59, 2008.

19. Brady CA, Jiang D, Mello SS, Johnson TM, Jarvis LA, Kozak MM, Kenzelmann Broz D, Basak S, Park EJ, McLaughlin ME, et al: Distinct p53 transcriptional programs dictate acute DNA-damage responses and tumor suppression. Cell 145: 571-583, 2011.

20. Harvey AL: Natural products in drug discovery. Drug Discov Today 13: 894-901, 2008.

21. Ciolino HP, Wang TT and Yeh GC: Diosmin and diosmetin are agonists of the aryl hydrocarbon receptor that differentially affect cytochrome P450 1A1 activity. Cancer Res 58: 2754-2760, 1998.

22. Takeuchi H, Yokota A, Ohoka Y and Iwata M: Cyp26b1 regulates retinoic acid-dependent signals in $\mathrm{T}$ cells and its expression is inhibited by transforming growth factor- $\beta$. PloS One 6: e16089, 2011.

23. Nagaraj NS and Datta PK: Targeting the transforming growth factor-beta signaling pathway in human cancer. Expert Opin Investig Drugs 19: 77-91, 2010.

24. Perrot CY, Javelaud D and Mauviel A: Insights into the transforming growth factor- $\beta$ signaling pathway in cutaneous melanoma. Ann Dermatol 25: 135-144, 2013.

25. Speidel D: Transcription-independent p53 apoptosis: An alternative route to death. Trends Cell Biol 20: 14-24, 2010.

26. Javelaud D, Alexaki VI, Dennler S, Mohammad KS, Guise TA and Mauviel A: TGF- $\beta /$ SMAD/GLI2 signaling axis in cancer progression and metastasis. Cancer Res 71: 5606-5610, 2011.

27. Lee JH, Gaddameedhi S, Ozturk N, Ye R and Sancar A: DNA damage-specific control of cell death by cryptochrome in p53-mutant ras-transformed cells. Cancer Res 73: 785-791, 2013.

28. Burmakin M, Shi Y, Hedström E, Kogner P and Selivanova G: Dual targeting of wild-type and mutant p53 by small molecule RITA results in the inhibition of N-Myc and key survival oncogenes and kills neuroblastoma cells in vivo and in vitro. Clin Cancer Res 19: 5092-5103, 2013. 